\title{
Nutrient composition of selected emergent macrophytes in Northern Prairie wetlands
}

DONALD R. KIRBY, DOUGLAS M. GREEN, AND THOMAS S. MINGS

\section{Abstract}

North Dakota's seasonal wetlands, covering 1.3 million ha, are an important forage resource especially during dry years. A study was initiated in south central North Dakota to determine forage quality of dominant emergent macrophytes. Ten species, American sloughgrass (Beckmannia syzigachne (Steud.) Fern.), tall mannagrass (Glyceria grandis S. Wats. ex A. Gray), common reed (Phragmites australis (Cav.) Trin. ex. Steud.), whitetop or sprangletop (Scolochloa festucacea (Willd.) Link), prairie cordgrass (Spartina pectinata Link), slough sedge (Carex atherodes Spreng.), spikerush (Eleocharis macrostachya Britt.), baltic rush (Juncus balticus Willd.), hardstem bulrush (Scirpus acutus Muhl.), and three square (Scirpus pungens Vahl.) were collected twice a month, from mid-May until mid-August then after first frost. After drying at $60^{\circ} \mathrm{C}$, samples were separated to leaf and stem where applicable. Analyses included in vitro dry matter digestibility (IVDMD), crude protein (CP), and phosphorus (P). Although species and season differences occurred, IVDMD, CP, and $P$ declined linearly with season in each plant species and part. Depending upon the species mix, wetland hay harvested between bloom and mature stages would be expected to average 47-49\% IVDMD, 7.6-14.0\% CP, and .17-.29\% P. Harvested early, mixed species wetland hays would provide adequate nutrients for dry pregnant cows. However, energy and $P$ supplementation may be necessary for late harvested wetland hays.

Key Words: wetlands, emergent species, nutrient composition

Seasonal wetlands cover about 1.3 million ha of North Dakota (Stewart and Kantrud 1973). Despite their small size, wetlands can produce over $3,000 \mathrm{~kg} / \mathrm{ha}$ of forage in wet meadows and over 5,000 $\mathrm{kg} /$ ha in shallow marshes (Fulton 1979 ). The high primary production of wetlands makes them attractive to ranchers as sources of forage and hay especially during drought years.

The earliest studies on the nutrient composition of aquatic plants appeared during the 1930's in response to a major drought (Gortner 1934, Harper and Daniel 1934, Christensen et al. 1947). Gortner (1934) reported aquatic plants high in crude protein (CP) and other nutrients. Clarke and Tisdale (1945), in southern Alberta and Saskatchewan, found CP lower and fiber similar in aquatic graminoids when compared to dominant upland short-grass species. Boyd (1968) concluded that, on a dry matter basis, aquatic plants are comparable to conventional forages in $\mathrm{CP}$ and mineral composition. Yalubovskiy and Merezhko (1975) found a high amino acid concentration in emergent macrophytes. Linn et al. (1975) suggested that aquatic plants were useful as forage for ruminants since many of the species they studied were high in CP and low in crude fiber. Linn et al. (1975) also found high levels of calcium, phosphorus (P), magnesium, potassium, sodium, iron,

\footnotetext{
Authors are associate professor, graduate research assistant and research associate, Animal and Range Sciences Department, North Dakota State University, Fargo

The authors would like to thank Mr. Paul Nyren, superintendent, Central Grasslands Research Station, for his assistance in this study. Special thanks to P.M. Swantek for assisting in statistical analysis. Financial support by the North Dakota Beef Commission is acknowled ged.

This article is published with the approval of the Director, North Dakota Agricultural Experiment Station as Journal Article 1712. Manuscript accepted 27 December 1988.
} 58105. manganese, and molybdenum in aquatic plants despite harvesting in August.

The use of aquatic plants as livestock forage has received limited attention in North Dakota although many of these species contribute significantly to grazed forage and to winter hay supplies. The objective of this study was to determine the nutritive quality of selected emergent macrophytes from seasonal wetlands in North Dakota.

\section{Materials and Methods}

The wetlands studied are located on the 2,200-ha Central Grasslands Research Station. The station is approximately $16 \mathrm{~km}$ northwest of Streeter, N.Dak. The research station is located in the Missouri Coteau, an area of low morainic hills deposited by stagnation and ablation of glacial ice during the Pleistocene epoch, 10-60 thousand years ago (Rau et al. 1962, Winters 1963). The region contains numerous potholes or kettles formed as a result of buried ice blocks melting within the till.

The climate is continental characterized by mild summers and cold winters. Average precipitation is $45 \mathrm{~cm}$ with $75 \%$ received between April and October. Total precipitation was $44 \mathrm{~cm}$ and 67 $\mathrm{cm}$ in 1985 and 1986, respectively. Average daily temperature is $4^{\circ}$ $\mathrm{C}$ with a high of $20^{\circ} \mathrm{C}$ in July and a low of $-14^{\circ} \mathrm{C}$ in January. Dominant upland species were typical of the mixed grass prairie (Whitman and Wali 1975).

Species chosen for nutrient analysis are considered primary or secondary emergent wetland species in North Dakota (Stewart and Kantrud 1971) which can be easily grazed or hayed. Species selected included 5 grasses: American sloughgrass (Beckmannia syzigachne (Steud.) Fern.), tall mannagrass (Glyceria grandis $\mathrm{S}$. Wats. ex A. Gray), common reed (Phragmites australis (Cav.) Trin. ex Steud.), whitetop or sprangletop (Scolochloa festucacea (Willd.) Link), and prairie cordgrass (Spartina pectinata Link). Grass-like species included: slough sedge (Carex atherodes Spreng.), spikerush (Eleocharis macrostachya Britt.), baltic rush (Juncus balticus Willd.), hardstem bulrush (Scirpus acutus Muhl.) and three square (Scirpus pungens Vahl.). Scientific nomenclature follows the Great Plains Flora Association (1986).

Four samples of each species were collected twice a month starting 21 May 1985 and 27 May 1986 and until mid-August then after first frost (Table 1). Four plants were selected randomly from large monotypic stands to insure a large quantity of unharvested plants for collection throughout the growing season. It required 4 different wetlands to collect all species.

Grass species were separated to leaf and stem. The leaf was separated from the culm where it joined the leaf sheath. Stem material contained the leaf sheath, inflorescences, and stems of the plant. No stem material was separated on the first sample date because elongation of the stem had not yet begun. Plant height, growth stage, and soil condition or water depth at each collection date are shown in Table 2. Samples were dried in a forced air oven at $60^{\circ} \mathrm{C}$ and ground with a Wiley mill to pass through a $1-\mathrm{mm}$ screen.

In vitro dry matter digestibility (IVDMD) was estimated by a 
Table 1. Dates when collections for nutrient analysis were made.

\begin{tabular}{lcc}
\hline \hline & \multicolumn{2}{c}{ Year } \\
\cline { 2 - 3 } Season & 1985 & 1986 \\
\hline Late spring & 21 May & 27 May \\
& 6 June & 10 June \\
Early summer & 21 June & 23 June \\
& 8 July & 11 July \\
Summer & 25 July & 21 July \\
& 15 August & 4 August \\
Late summer & 13 September & 21 August \\
& & 18 September
\end{tabular}

'Not sampled.

modification of Tilley and Terry (1963). Modifications included using a $250-\mathrm{mg}$ sample in $25 \mathrm{ml}$ of inoculum, 48-hour rumen microbe fermentation, then a 24-hour HCl-pepsin incubation. Standard forages of known in vivo digestibilities were included in each in vitro digestion trial to correct IVDMD to apparent digestibility. Rumen inoculum was obtained from an angus cow on an alfalfa (Medicago sativa $\mathrm{L}$.) hay diet. All assays were run in duplicate. Crude protein $(\mathrm{N} \times 6.25)$ was determined by methods described by the AOAC (1980). Phosphorus was determined with vanadate-molybdate, yellow color development measured with a Spectronic 20.

The general linear models (GLM) procedure of the Statistical Analysis System (SAS 1985) was used for each variable within plant grouping (grass leaf, grass stem, grass-like) to determine the relationship among species, seasons, interactions and between years. Polynomial regression was performed to partition the variation for seasons into linear, quadratic, and cubic effects. Pairwise comparisons of intercepts and slopes among species were made. Where similar $(P>0.05)$, intercepts and/or slopes were recalculated using the combined data set.

\section{Results}

Analysis showed data were similar $(P>0.05)$ between years, thus were combined. Species and season differences $(P<0.05)$ occurred among plant groupings (grass leaf, grass stem, grass-like) for each chemical component (IVDMD, CP, P). There were significant species and season interactions $(P<0.05)$ for IVDMD among grass leaf tissues and for CP among grass leaf tissues and grass-like species. There was also a significant interaction for $P$ among grass stem tissues and grass-like species.
For each species and part, IVDMD, $C P$, and $P$ declined linearly with season. Linear sums of squares among plant groupings accounted for 94 to $97 \%, 90$ to $96 \%$, and 83 to $93 \%$ of the total variation in IVDMD, $C P$, and $P$, respectively.

Regression equations for IVDMD and CP differed $(P<0.05)$ among plant groupings. As a group, the IVDMD of grass stems were initially lower than that of grass leaves or grass-like species, but declined less rapidly with season. Percentage $C P$ was greatest in grass leaves and least in grass stems. The percentage of $\mathrm{CP}$ of leaves had a steeper seasonal decline than that in grass stems or grass-like species. Regression equations for $P$ were similar among plant groupings.

The IVDMD of American sloughgrass and prairie cordgrass leaves and stems were higher than the other grass species (Fig. 1). Of the grass-like species, IVDMD of three square was higher throughout the growing season when compared to baltic rush. Leaf IVDMD of tall mannagrass, common reed and whitetop, and all grass-like species had similar rapid seasonal declines.

The percentage $\mathrm{CP}$ in common reed, whitetop, and prairie cordgrass leaves was initially high, near or exceeding $20 \%$, but common reed leaf tissue alone maintains high $C P$ levels throughout the growing season (Fig. 2). However, CP in common reeds' stems is low throughout the growing season. Spikerush began the growing season with the highest CP concentration but decreased rapidly and by late summer was the lowest of the grass-like species.

Leaf $P$ decreased similarly with advancing seasons (Fig. 3). The $P$ concentration of leaf tissue of whitetop and stem tissue of American sloughgrass and tall mannagrass maintained higher seasonal levels compared to common reed. However, $P$ in stem tissues of American sloughgrass and tall mannagrass decreased at a more rapid rate compared to other species. As reported for $C P$, the $P$ concentration in spikerush began the growing season higher than the remaining grass-like species but decreased to levels below the other grass-like species by late summer.

\section{Discussion}

Wetland species analyzed in this study provide data that generally agree with previously published information for these species (Gortner 1934, Clarke and Tisdale 1945, Nicholson and Langille 1965, Boyd 1968, Smith 1973, Linn et al. 1975, Fulton et al. 1986). However, complete comparisons are difficult due to lack of information on collection methodology in most earlier studies. Comparisons of IVDMD were not made due to a lack of previous information on wetland species.

Table 2. Plant height $(\mathrm{cm})$ and growth stage, and soil condition or water depth $(\mathrm{cm})$ at the time of seasonal collections.

\begin{tabular}{|c|c|c|c|c|c|c|c|c|c|c|c|}
\hline \multirow[b]{2}{*}{ Datel } & & \multicolumn{5}{|c|}{ Grasses $^{2}$} & \multicolumn{5}{|c|}{ Grass-likes $^{2}$} \\
\hline & & Besy & Glgr & Phau & Scfe & Sppe & Caat & Elma & Juba & Scac & Scpu \\
\hline Late spring & $\begin{array}{l}\text { HT(cm) } \\
\text { GS } \\
\text { S/W(cm) }\end{array}$ & 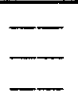 & $\begin{array}{r}28 \\
\text { Veg } \\
\text { sat }\end{array}$ & $\begin{array}{r}99 \\
\text { Veg } \\
4\end{array}$ & $\begin{array}{r}30 \\
\text { Veg } \\
22\end{array}$ & $\begin{array}{r}29 \\
\text { Veg } \\
3\end{array}$ & $\begin{array}{r}34 \\
\text { Veg } \\
5\end{array}$ & $\begin{array}{l}21 \\
\text { B1 } \\
14\end{array}$ & $\begin{array}{c}32 \\
\text { B1 } \\
\text { damp }\end{array}$ & $\begin{array}{r}103 \\
\text { B1 } \\
13\end{array}$ & $\begin{array}{l}45 \\
B 1 \\
14\end{array}$ \\
\hline $\begin{array}{l}\text { Early } \\
\text { summer }\end{array}$ & $\begin{array}{l}\text { HT(cm) } \\
\text { GS } \\
\text { S/W(cm) }\end{array}$ & $\begin{array}{r}78 \\
\text { B1 } \\
1\end{array}$ & $\begin{array}{r}83 \\
\text { B1 } \\
4\end{array}$ & $\begin{array}{r}213 \\
\text { Veg } \\
10\end{array}$ & $\begin{array}{l}86 \\
\text { B1 } \\
41\end{array}$ & $\begin{array}{r}85 \\
\text { Veg } \\
1\end{array}$ & $\begin{array}{l}59 \\
B 1 \\
15\end{array}$ & $\begin{array}{r}49 \\
\mathrm{~B} 1 \\
7\end{array}$ & $\begin{array}{r}62 \\
B 1 \\
\text { damp }\end{array}$ & $\begin{array}{r}188 \\
\text { B1 } \\
16\end{array}$ & $\begin{array}{r}74 \\
\text { B1 } \\
\text { sat }\end{array}$ \\
\hline $\begin{array}{l}\text { Mid } \\
\text { summer }\end{array}$ & $\begin{array}{l}\text { HT(cm) } \\
\text { GS } \\
\text { S/W(cm) }\end{array}$ & $\begin{array}{r}74 \\
\text { Mat } \\
3\end{array}$ & $\begin{array}{c}99 \\
\text { Mat } \\
\text { damp }\end{array}$ & $\begin{array}{r}190 \\
\mathrm{~B} 1 \\
6\end{array}$ & $\begin{array}{r}90 \\
\text { Mat } \\
38\end{array}$ & $\begin{array}{r}71 \\
\text { B1 } \\
1\end{array}$ & $\begin{array}{r}70 \\
\text { Mat } \\
5\end{array}$ & $\begin{array}{r}52 \\
\text { Mat } \\
9\end{array}$ & $\begin{array}{c}60 \\
\text { Mat } \\
\text { damp }\end{array}$ & $\begin{array}{c}197 \\
\text { Mat } \\
11\end{array}$ & $\begin{array}{r}75 \\
\text { Mat } \\
3\end{array}$ \\
\hline $\begin{array}{l}\text { Late } \\
\text { summer }\end{array}$ & $\begin{array}{l}\text { HT(cm) } \\
\text { GS } \\
\text { S/W(cm) }\end{array}$ & $\begin{array}{r}79 \\
\text { Pst } \\
5\end{array}$ & $\begin{array}{c}104 \\
\text { Pst } \\
\text { damp }\end{array}$ & $\begin{array}{c}242 \\
\text { Mat } \\
\text { sat }\end{array}$ & $\begin{array}{r}82 \\
\text { Pst } \\
43\end{array}$ & $\begin{array}{r}96 \\
\text { Mat } \\
2\end{array}$ & $\begin{array}{r}70 \\
\text { Pst } \\
6\end{array}$ & $\begin{array}{r}48 \\
\text { Pst } \\
1\end{array}$ & $\begin{array}{r}62 \\
\text { Mat } \\
\text { dry }\end{array}$ & $\begin{array}{r}196 \\
\text { Mat } \\
6\end{array}$ & $\begin{array}{c}78 \\
\text { Mat } \\
\text { sat }\end{array}$ \\
\hline
\end{tabular}

${ }^{1}$ Late spring (21 May-10 June), Early summer (21 June-11 July)), Mid summer (21 July-4 August), Late summer (15 August-18 September).

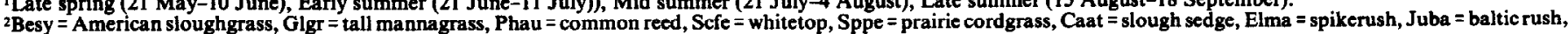

Scac $=$ hardstem bulrush, $\mathrm{Scpu}=$ three square.

3Growth stages are: $\mathrm{Veg}=$ vegetative, $\mathrm{Bl}=$ bloom, Mat $=$ seed, Pst $=$ Postripe.

4Soil conditions are saturated, damp, and dry. 


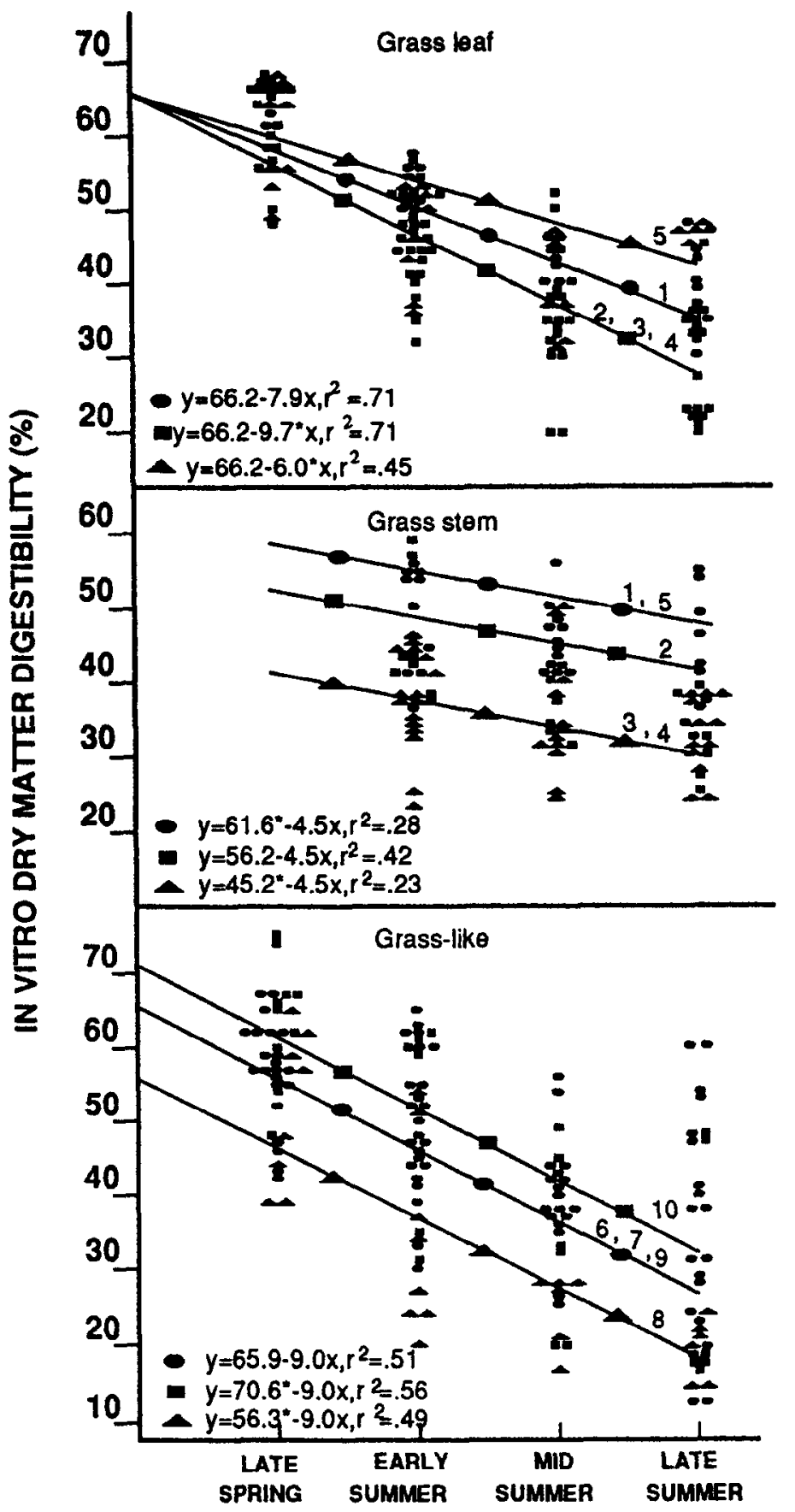

Fig. 1. In vitro dry matter digestibility of American sloughgrass (1), tall mannagrass (2), common reed (3), whitetop (4), prairie cordgrass (5), slough sedge (6), spikerush (7), baltic rush (8), hardstem bulrush (9), and three square (10). Intercepts or slopes followed by an asterisk differ $(\mathbf{P}<0.05)$.

The nutrient composition of wetland species examined was similar to that of widely used regional hays. Crested wheatgrass (Agropyron cristatum L. Gaertn.), smooth brome (Bromus inermis Leyss.) and mixed prairie hay harvested between bloom and mature stages (mid June to mid July) have total digestible nutrients (TDN), CP, and $P$ concentrations ranging from $51-55 \%, 5.8-12.4 \%$, and .15-.35\% respectively (NRC 1984). Using our regression equations, IVDMD corrected to apparent digestibility (roughly equivalent to \% TDN), averaged $47-49 \%$ for the grass and grass-like

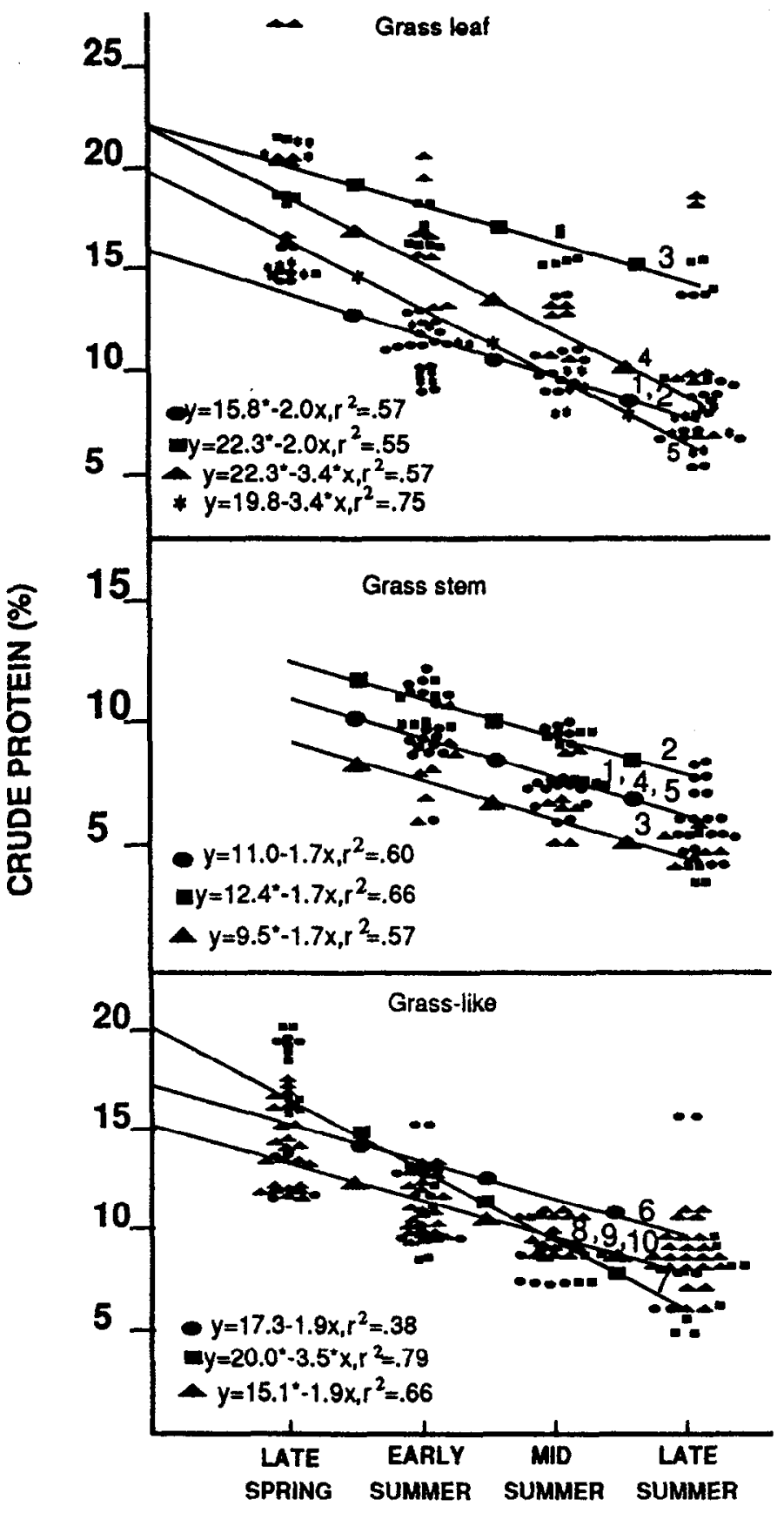

Fig. 2. Crude protein ( $N \times 6.25)$ in American sloughgrass (1), tall mannagrass (2), common reed (3), whitetop (4), prairie cordgrass (5), slough sedge (6), spikerush (7), baltic rush (8), hardstem bulrush (9), and three square (10). Intercepts or slopes followed by an asterisk differ $(\mathrm{P}<0.05)$.

species in early summer (late June to mid July). For the same period, $\mathbf{C P}$ and $\mathbf{P}$ in grass and grass-like species averaged $7.6 \%-14.0 \%$ and $.17-29 \%$, respectively.

Lactating requirements for averaging milking $450 \mathrm{~kg}$ cows are $57.5 \%$ TDN, $9.9 \%$ CP, and .23\% P (NRC 1984). Mixed wetland hay would only be expected to meet these requirements in late spring (late May to early June). Water levels in wetlands generally prohibit haying at this time. However, cows are generally dry and pregnant in winter when wetland hays would normally be fed. Dry, 


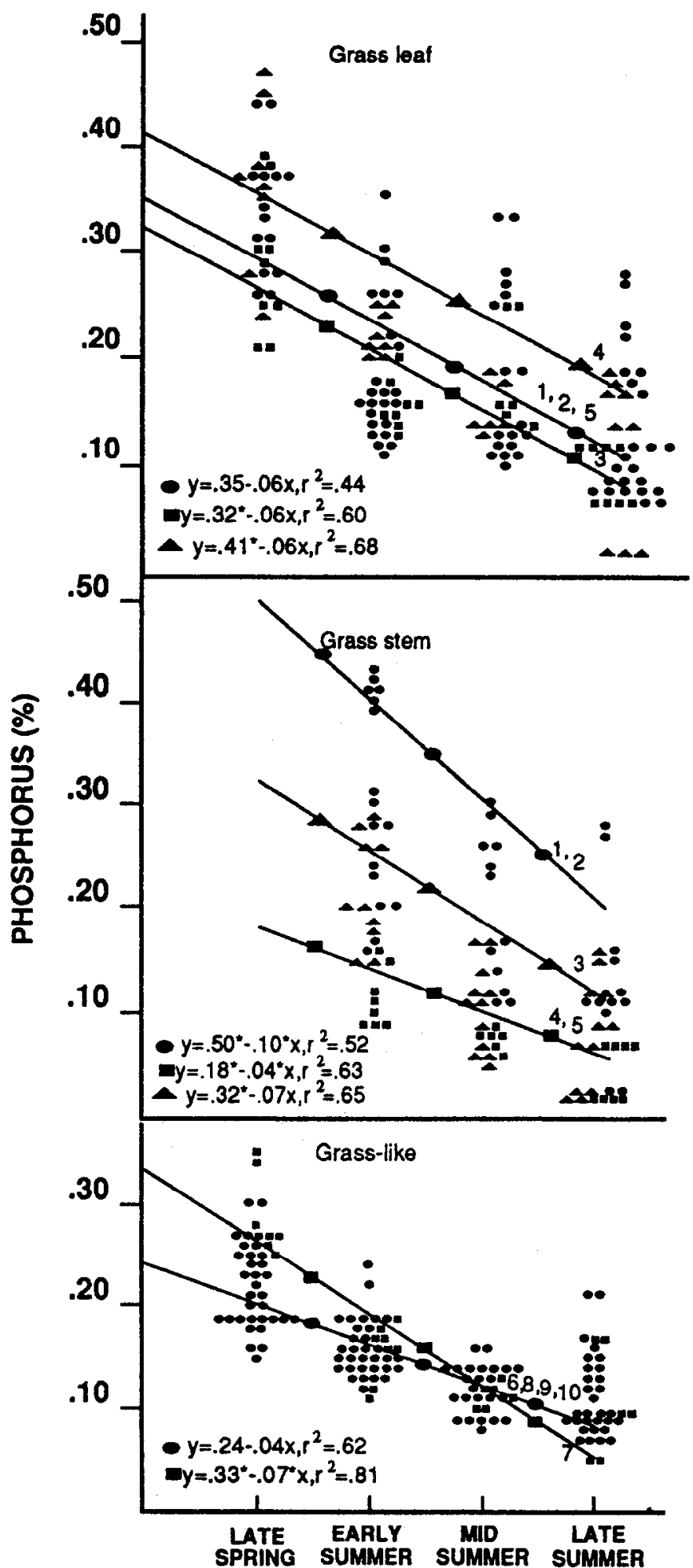

Fig. 3. Phosphorus content of American sloughgrass (1), tall mannagrass (2), common reed (3), whitetop (4), prairie cordgrass (5), slough sedge (6), spikerush (7), baltic rush (8), hardstem bulrush (9), and three square (10). Intercepts or slopes followed by an asterisk differ $(\mathrm{P}<0.05)$. pregnant cow $(450 \mathrm{~kg}$ ) requirements are $48.6 \% \mathrm{TDN}, 7.0 \% \mathrm{CP}$, and $.18 \% \mathrm{P}$. Mixed wetland hays would provide sufficient TDN and $\mathrm{P}$ if harvested through early summer (mid July) and meet CP requirements through summer (August 15). Harvested early, mixed wetland hays would provide adequate nutrients for dry, pregnant cows. However, energy and $P$ supplementation may be necessary when feeding late harvested wetland hays.

\section{Literature Cited}

AOAC. 1980. Official methods of analysis. (13th ed.) Association of Official Analytical Chemists. Washington, D.C.

Boyd, C.E. 1968. Freshwater plants: A potential source of protein. Econ. Bot. 22:359-368.

Christensen, F.W., T.H. Hopper, and O.A. Stevens. 1947. Feeding slough hays and oat straw. North Dakota Agr. Exp. Sta. Bull. 349.

Clarke, S.B., and B.W. Tisdale. 1945. The chemical composition of native forage plants of southern Alberta and Saskatchewan in relation to grazing practices. Can. Dep. Agr. Tech. Bull. No. 54.

Fulton, G.W. 1979. Wetland vegetation in southwestern North Dakota. MS. Thesis. North Dakota State Univ. Fargo.

Fulton, G.W., J.L. Richardson, and W.T. Barker. 1986. Wetland soils and vegetation. N.D. Res. Rep. 106.

Gortner, R.A. 1934. Lake vegetation as a possible source of forage. Science 80:531-533.

Great Plains Flora Association. 1986. Flora of the Great Plains. Univ. Kansas Press. Lawrence.

Harper, H.J., and H.A. Daniel. 1934. Chemical composition of certain aquatic plants. Bot. Gaz. 96:186-189.

Linn, G.C., E.J. Staba, R.D. Goodrich, J.C. Meinke, and D.E. Otterby. 1975. Nutritive value of dried ensile aquatic plants. I. Chemical composition. J. Anim. Sci. 41:601-609.

NRC. 1984. Nutrient requirements of domestic animals; No. 4. Nutrient requirement of beef cattle. National Academy of Sciences-National Research Council. Washington, D.C.

Nicholson, J.W.G., and J.E. Langille. 1965. The comparative nutritive value of Spartina pectinata and timothy at several stages of growth. Can. J. Anim. Sci. 45:157-163.

Rau, J.L., W.E. Bakken, J. Chmelik, and B.J. Williams. 1962. Geology and ground water resources of Kidder County, North Dakota. Part 1, Geology. North Dakota Geological Survey Bull. 36, North Dakota Geol. Survey, Grand Forks.

SAS. Institute. 1985. SAS User's Guide: Statistics. Cary, North Carolina.

Smith, A.L. 1973. Production and nutrient status of whitetop. J. Range Manage. 26:117-119.

Stewart, R.E., and H.A. Kantrud. 1971. Classification of natural ponds and lakes in the glaciated prairie region. Res. Pub. 92. Bureau of Sport Fisheries and Wildlife.

Stewart, R.E., and H.A. Kantrud. 1973. Ecological distribution of breeding populations in North Dakota. J. Wildl. Manage. 37:39-50.

Tilley, J.M.A., and R.A. Terry. 1963. A two stage technique for the in vitro digestion of forage crops. J. Br. Grassl. Soc. 18:104-111.

Whitman, W.C., and M.K. Wali. 1975. Grasslands of North Dakota, p. 21-38. In: M.K. Wali (ed). Prairie: A multiple view. Univ. North Dakota Press, Grand Forks.

Winters, H.A. 1963. Geology and ground water resources of Stutsman County North Dakota, Part 1, Geology. North Dakota Geological Survey Bull. 41, North Dakota Geol. Survey, Grand Forks.

Yakubovskiy, K.B., and A.F. Merezhko. 1975. Carbohydrates and the nitrogen compounds of several higher aquatic plants and variations in their content during the growing season. Hydrobiol. J. 11:64-67. 